\title{
The place of child development in evaluations related to custody in Turkey
}

\author{
Sebahat Aydos ${ }^{1}$ and Aysel Köksal Akyol ${ }^{1}$
}

\begin{abstract}
The aim of this study is to examine the reports prepared in the process of deciding the custody of children in divorced families in the context of child development. The reports evaluated in the scope of the research were evaluated by the method of document review and the results were found in the context of child development and the best interest of the child. In this context, a total of 107 reports related to custody were examined. The results from findings show that while evaluations regarding custody are expressed in many places with the emphasis on the development of the children, the reports contain little information about the development of the child. When the child's best interest is considered to be the most important component of child development, it is seen that as a result of these depictions, developing a new system in order to protect the best interest of the child, which is one of the top principles of the law related to custody, and carrying out an evaluation that focuses on child development is necessary.
\end{abstract}

Keywords: child custody; child development; custody evaluation; Turkey

1. Department of Child Development, Faculty of Health Science, Ankara University

Address for correspondence: sebahatcalis@hotmail.com

Date of first (online) publication: 31st March 2021 


\section{Introduction}

The concept of divorce having an impact on the development of the child witnessing divorce, which is sure to have a significant impact on the lives of the adults in this social process, is an inevitable consequence. When we look at the laws of Turkey, the legal definition of divorce is when a marriage which took place in accordance with the law is terminated by a court decision leaving no connection between the spouses and in a case where a child in common is concerned, the protection of their rights (Uzun, 2013).

From a social point of view it is possible for divorce to be seen as merely a 'separation between spouses'. Although we may occasionally think of divorce as normal in terms of specific events, this conclusion would be overly simplifying the concept of divorce. Because divorce directly affects not only the married couple but also other members of the family and the children who may also plan to start a family of their own in the future (Tatlığlu \& Demirel, 2016). The group which is mostly affected by divorce and where a negative impact is mostly seen is the children (Bilici, 2014). After a divorce takes place, the lifestyle the children are accustomed to completely changes and it is highly likely that the children are forced to be apart from one of their parents (Uzun, 2013). Also, all of the positive and negative experiences the children go through during this period will shape their future. For this reason, the decisions taken regarding the child's life are important for the child as an individual, and socially in terms of raising a healthier generation.

When the effects of divorce on children are examined, three important problems arise. The first of these problems is the effect that divorce has on a child's daily life. The second problem is the age and development period which the child is in during the process of divorce. The third problem is custody. After the divorce takes place, important concepts regarding the child's future life will be formed, with the custodial decision which determines who the child will stay with and the state of the personal relationship with the other parent. For this reason, the decision regarding custody plays an important role in terms of the effect of the divorce on the child (Cüceloğlu, 2015).

Custody includes all the responsibilities and authority that parents have regarding their children. In the event of a divorce, the parent who does not gain custody of the child will not be able to use any parental rights concerning the child and will not be able to intervene in the parent who has custody (Kiremitçi, 2014). Although the concept of 'quality time' is more important from the concept of 'more time' in terms of development, it has been revealed in various research that there is a possibility of a negative impact on a child who is forced to grow up with one parent absent, especially when it comes to concepts such as trust and bonding (Çınar, 2015; Fiyakalı 2008, Özdal \& Aral, 2006; Öztürk, 2006). Undoubtedly, one of the factors that will reduce this negative impact is the status of the parent who has the child's custody. For this reason, the determinants that will protect the child's best interests should 
be effective when deciding what is 'right' for the child. In the custody process, the development of the child is as important as the age of the child, the socioeconomic and cultural status of the family and other parameters. Many of the parameters mentioned in the decision of the courts are directly or indirectly related to the development of the child.

Before accepting Islam, Turks had a paternal family order. Anna could only have custody in the absence of the father. In this period, other than parents could have the right to custody. After the acceptance of Islam in Turks, the right to custody until the adoption of the civil law belonged to the father. If the father became unable to use custody, another guardian would be appointed instead. Mother's custody could never take. He could have been the most guardian. Therefore, he had to fulfill many conditions (Çetiner, 2017).

The Turkish Civil Code was prepared based on the Swiss Civil Code and was adopted in 1926. In the context of family law, men and women have become equal with this law. In other words, the woman has the right to have custody of the child from this date. In 2002, the civil law was renewed and went to legislation. According to this law, which is still used today, custody marriage is used jointly by parents. In case of divorce, the judge gives the custody of the child to one of the parents. Joint custody is not yet a law passed to the method in Turkey. The decision of whom to custody is entirely dominated.

Although the concept of the best interests of the child after the adoption of the Convention on the Rights of the Child is considered as the roof concept of Turkish law, the fact that the common custody is not regulated by law reduces the applicability of this roof concept. The reason for this can be explained as follows: According to Kelly, the high (superior) benefit of the child is the combination of the factors that the child needs in organizing a custody and / or personal relationship where he can adapt and continue his development. For this reason, each child should be evaluated individually and the decision corresponding to his needs should be made to ensure that most of them benefit most. If a child needs common custody to protect the best interests of the child, the Turkish legal system does not allow this.

According to the Turkey Statistical Institute data, marriages declining in Turkey, while divorces is increasing. In 2018, marriages decreased by $2.3 \%$ compared to 2017, while the number of divorced couples increased by $8 \%$.

Courts are the sole authority in divorces. If the divorces are agreed, the process proceeds more easily, but if it is contentious, the process is both prolonged and difficult. The custody decision is made by the judge, whether contested or contentious. Even in consensual divorces, the judge can make a custody decision, contrary to the agreement of the spouses.

In assessments regarding custody, the decision is entirely up to the court judge. However, within the scope of the Law on the Establishment, Duties and Trial Procedures of the Turkish Family Courts expert personnel is employed in the family courts, and this personnel prepares an evaluation report upon the request 
of the judge. Each of the reports may differ depending on many variables such as the court being requested, the profession of the expert who prepared the report and the conditions of the examiner.

In order to reach a decision regarding the custody of a child, it is important to determine the child's developmental status, to know the characteristics of the child's developmental period, and to ensure that the decision is supported according to these characteristics. This is because the child's social development, character development and the general difference seen according to the development stages are the attributes that should be considered when making decisions regarding custody. If it is not considered, it is likely that a decision which is not in the best interest of the child whose custody is in question has been taken. Because in order for the child to lead a normal and healthier life in terms of development, and become a useful person to society the decision regarding custody is without a doubt of utmost importance.

When the related literature is examined, it is seen that many studies related to custody have been carried out, but these studies have generally dealt with the legal side of the process. The existence of studies also related to guidelines for the preparation of reports by experts working in courts (APA, 1994; Martindale, 2007; Luftman et al., 2005), assessments according to the content and formality of the reports by experts employed by family courts (Ackerman \& Ackerman, 1997; Bow \& Quinell, 2002; Bow \& Quinell, 2004; Üner Altuntaş, 2010;), determining the experts in-service training needs (Kılıç, 2013), the importance of expert opinion (Buz et al., 2015) is observed. However, it has been seen from reports prepared by experts who are highly responsible in regards to custody, that there are no studies focusing on evaluating the child's development in Turkish literature.

For these reasons, the aim of this study is to examine the reports prepared in the process of deciding the custody of children in divorced families in Turkey in the context of child development.

\section{Method}

In this study, the aim is to investigate the period of deciding the custody of children in divorced families based on the custody reports in the context of child development. In order to carry out this study, firstly a confirmation by the Ethics Committee of the University of Ankara was received approving that the study is ethical. After this, the reports were received in electronic form, from the court evaluating the reports with the personal information removed.

The reports evaluated in the scope of the research were evaluated by the method of document review and the results were found in the context of child development and the best interest of the child. The format of the research is a document review based on the descriptive scanning model. The reports within the scope of the 
research were evaluated using the method of document review, analyzed with the content analysis method used in the qualitative research methods and frequency analysis was applied to the data.

\section{Study group}

The research study group generated custody reports of the process of deciding the custody of the children whose families were broken up due to divorce between 2013 and 2015 at a family court chosen incidentally by typical sampling method. This data was collected as the secondary data in qualitative research methods. It was decided to conduct an evaluation of the study by going back three years. The reason why the working group is selected like this is to facilitate the availability of the data and to enable the evaluation in a sufficient amount of time. In this context, a total of 107 reports related to custody were examined. $25.2 \%$ of these reports belong to the year 2013, 54.2\% belong to the year 2014 and 20.6\% belong to the year 2015 .

\section{Data collection tool}

The 107 custody reports constituting the research group were evaluated with a 'Checklist' which was formed by the researchers and completed with their expert opinions in order to evaluate the contents of the reports. The 'Checklist', which was created by the researchers for the content analysis dimension of the reports related to the custody of the research, was prepared after conducting a review of field literature. Consisting of 47 items, the Checklist contains the content that is included in the custody reports and the items to be included according to the literature. In order to ensure the content validity of the prepared draft form, the form was sent to seven specialists working in different fields (a specialist in qualitative research methods, three experts working in the field of child development and a specialist in educational sciences). The draft was revised according to the recommendations of the experts and the final form consists of 54 items. The checklist contains the following information: the year of the report that is examined, the subject of the report and the plaintiff-defendant information, the demographic information of the parents and the children whether they are subject to custody or not, the dependency of the parents, the reason for divorce, the behaviors of the parents towards their children, the information of the interviews with parents, the visits conducted to the houses of mother and father, the persons that are interviewed other than motherfather, the health status of the mother-father and the nature of relationship with the core family, the information on the development of the children, the standard measurement tools, such as tests and inventory, that are conducted to the children and mother-father, the visits conducted to the children's schools, information on 
who is providing the care for children before and during the divorce, information on the professional experience of the experts preparing the report and the opinion of the experts at the end of the report.

\section{Data collection}

After determining the subject of the study, Ankara Sihhiye Courthouse Justice Commission was interviewed. After the interview, the Justice Commission randomly referred to one of the 11 family courts in the Sihhiye Courthouse in Ankara. The research was carried out in Ankara, the capital of the country. Accordingly, this province, which is already a cosmopolitan structure, represents the general structure of the country. In addition, rules and laws are the same throughout the country and cannot be changed. Differences in applications are also due to individuals. However, these differences cannot go beyond certain frameworks. Therefore, the data of this study can be generalized in the context of Turkey.

A detailed information was shared with the court administrator about the purpose of the investigation. The purpose of the study, the requirements, the applications made abroad were shared. After providing verbal information, the research proposal including other documents is submitted to the court for review. After the documents are examined by the Court, the permission was obtained from the relevant Family Court on November 16, 2016. Hence, the Court Administrator directed the researcher to the experts preparing the reports. After getting an appointment, an interview was conducted with the specialists and the information about the details of the research was shared. On a date determined collectively with the experts that prepare the reports, the reports were received from the experts after they deleted the personal information on the reports.

\section{Data analysis}

The reports related to custody were read for evaluation and were subjected to a content analysis and the relevant fields in the Control List were filled. The data, which was coded on the checklists, evaluated as categories and finally converted into themes, was transferred to the relevant analysis program after the content analysis was completed and the frequency distributions of the data were examined. While $43.9 \%$ of the children who are subject of custody are girls, $54.9 \%$ are boys. In the report, data on the gender of two of the children who were subject of the custody were not shared. If we examine the age of the children, who are subject of the custody, we observe that $25.0 \%$ of the children are between 4 and 6 years old, while $24.5 \%$ of the children between 7 and 9 years old. The reports included 14 children, whose custody was not discussed. While $71.5 \%$ of them are above 
18 years of age, therefore, the custody status is not evaluated,14.3\% of them have different mothers and $7.1 \%$ have different fathers. Again, the information about the remaining percentage (7.1\%) isn't given in the report.

\section{Results}

Table 1

Distributions related to negotiations made during the custodial decision making process

\begin{tabular}{|c|c|c|c|}
\hline & & $\mathrm{N}$ & $\%$ \\
\hline \multirow{3}{*}{$\begin{array}{l}\text { Interview with the } \\
\text { mother }\end{array}$} & Yes & 87 & 81.2 \\
\hline & No & 20 & 17.8 \\
\hline & Total & 107 & 100.0 \\
\hline \multirow{3}{*}{$\begin{array}{l}\text { Interview with the } \\
\text { father }\end{array}$} & Yes & 90 & 84.1 \\
\hline & No & 17 & 15.9 \\
\hline & Total & 107 & 100.0 \\
\hline \multirow{4}{*}{$\begin{array}{l}\text { Interview with the } \\
\text { mother }\end{array}$} & Courthouse & 80 & 92.0 \\
\hline & Home & 4 & 4.6 \\
\hline & $\begin{array}{l}\text { Both at courthouse and } \\
\text { at home }\end{array}$ & 3 & 3.4 \\
\hline & Total & 87 & 100.0 \\
\hline \multirow{4}{*}{$\begin{array}{l}\text { Interview with the } \\
\text { father }\end{array}$} & Courthouse & 83 & 92.3 \\
\hline & Home & 6 & 6.6 \\
\hline & $\begin{array}{l}\text { Both at courthouse and } \\
\text { at home }\end{array}$ & 1 & 1.1 \\
\hline & Total & 90 & 100.0 \\
\hline
\end{tabular}




\begin{tabular}{|c|c|c|c|}
\hline \multirow{3}{*}{$\begin{array}{l}\text { Interview with close } \\
\text { relations }\end{array}$} & Yes & 3 & 2.8 \\
\hline & No & 104 & 97.2 \\
\hline & p. 9 , para 2 from bottom, li & $\begin{array}{c}107 \\
\text { he } 2: \text { As we I hay }\end{array}$ & ve argued; replas \\
\hline \multirow{3}{*}{$\begin{array}{l}\text { Visit to the mother's } \\
\text { house }\end{array}$} & $\begin{array}{l}\text { p. } 9 \text { line } 5 \text { : which are is cal } \\
\text { p.9, last para, line } 3 \text { : does }\end{array}$ & $\begin{array}{l}\text { used; replace 'are } \\
\text { hot seem; plural }\end{array}$ & ' with 'is's \\
\hline & $\mathrm{p} .1 \mathrm{H}_{0}$ last line: learn who h & bw bess: replace & "who'grifth 'hoy \\
\hline & Total & 107 & 100.0 \\
\hline \multirow{3}{*}{$\begin{array}{l}\text { Suitability of the } \\
\text { mother's house for the } \\
\text { child }\end{array}$} & Suitable & 8 & 88.9 \\
\hline & Unsuitable & 1 & 11.1 \\
\hline & Total & 9 & 100.0 \\
\hline \multirow{3}{*}{$\begin{array}{l}\text { Visit to the father's } \\
\text { house }\end{array}$} & Yes & 8 & 7.5 \\
\hline & No & 99 & 92.5 \\
\hline & Total & 107 & 100.0 \\
\hline \multirow{3}{*}{$\begin{array}{l}\text { Suitability of the father's } \\
\text { house for the child }\end{array}$} & Suitable & 7 & 87.5 \\
\hline & Unsuitable & 1 & 12.5 \\
\hline & Total & 8 & 100.0 \\
\hline \multirow{3}{*}{$\begin{array}{l}\text { The mother's statement } \\
\text { regarding her home }\end{array}$} & Yes & 74 & 75.5 \\
\hline & No & 24 & 24.5 \\
\hline & Total & 98 & 100.0 \\
\hline \multirow{3}{*}{$\begin{array}{l}\text { The suitability of the } \\
\text { statement regarding the } \\
\text { mother's home }\end{array}$} & Suitable & 72 & 97.3 \\
\hline & Unsuitable & 2 & 2.7 \\
\hline & Total & 74 & 100.0 \\
\hline
\end{tabular}




\begin{tabular}{|c|c|c|c|}
\hline \multirow{3}{*}{$\begin{array}{l}\text { The father's statement } \\
\text { regarding his home }\end{array}$} & Yes & 75 & 75.75 \\
\hline & No & 24 & 24.25 \\
\hline & Total & 99 & 100.0 \\
\hline \multirow{3}{*}{$\begin{array}{l}\text { The suitability of the } \\
\text { statement regarding the } \\
\text { father's home }\end{array}$} & Suitable & 70 & 93.4 \\
\hline & Unsuitable & 5 & 6.6 \\
\hline & Total & 75 & 100.0 \\
\hline
\end{tabular}

Table 1 provides information regarding interviews with the parents and home visits conducted during the writing process of custodial reports. According to the table, $81.3 \%$ of the mothers who were the subjects of the case were interviewed but $17.8 \%$ were not interviewed. The rate of interviews for the fathers is $84.1 \%$. While $92 \%$ of interviews with the mothers were conducted at the courthouse, $3.4 \%$ were interviewed both at the courthouse and in a home environment. When the interviews conducted with the parents were evaluated, $92.3 \%$ of them were interviewed at the courthouse, while only $1.1 \%$ of them were interviewed in both the courthouse and a home environment. It is also stated that only $2.8 \%$ of the reports provided interviews with the children's close relations. Among the information obtained from the reports, it is seen that the reason for interviews not being conducted with the parents is because they either lived in a different province or they refused to be interviewed. Besides, it is considered that the interviews carried out with the parents in a courthouse environment are not appropriate because it may cause problems in terms of obtaining the correct data. It was seen in $91.6 \%$ of the reports that visits to the mother's house did not take place. The rate of visits to the father's house was 92.5\%. Bow and Quinell (2004) assessed the reports prepared by experts regarding custody, in a study they conducted and concluded that home visits took place in $34.6 \%$ of the reports. When we look at the findings of another study by Bow and Quinell (2002), it is seen that 22\% of parent-child observations are performed in the home environment. When the study conducted and both studies of Bow and Quinell are compared, it can be concluded that there were very few home visits conducted during the preparation of the reports evaluated in this study. Stahl (2012) stated that home visits give experts a chance to assess the parents and the relationship between them. Lufthman et al. (2005) noted the importance of home visits in a guide prepared for social workers regarding child custody assessments. A home visit can provide information for the expert on such factors as the physical space, safety, the location, or maintenance. When there is a substantial claim as a result of a home visit, a referral to social services may be needed (Lufthman et al. 2005). In a study conducted by Üner Altuntaş (2010), he stated that in Turkey home visits in 
assessments regarding custody are undervalued. It would not be wrong to interpret the findings obtained in this study the same way.

When the importance of home visits are evaluated, we see that; the dynamics of the relationships change with home visits, the parents feel more at ease, communicate more easily, share their opinions and feelings more easily, and ask questions more easily. With this, the parents' values, attitudes, and behaviors towards the child can be learned. Home visits provide the opportunity to observe the home environment of the child, the relationship they have with the parents, and the responsibilities they have at home (MEB, 2013). It is known that observing the home environment, determining the facilities available inside the home, the observation of the child and the parents in the home environment, and seeing how these findings relate to how the home environment affects the child's development at the end of these observations can be evaluated in the decision making process related to custody and how these findings have an important effect in terms of the final decision. For this reason, it is considered that evaluations related to the custody in the context of child development are one of the indispensable evaluational steps.

Table 2

Distributions related to the information in the report regarding the development of the child in the custody battle

\begin{tabular}{|c|c|c|c|}
\hline & & $\mathrm{N}$ & $\%$ \\
\hline \multirow{3}{*}{ Interview with the mother } & Yes & 87 & 81.2 \\
\hline & No & 20 & 17.8 \\
\hline & Total & 107 & 100.0 \\
\hline \multirow{3}{*}{ Interview with the father } & Yes & 90 & 84.1 \\
\hline & No & 17 & 15.9 \\
\hline & Total & 107 & 100.0 \\
\hline \multirow{4}{*}{ Interview with the mother } & Courthouse & 80 & 92.0 \\
\hline & Home & 4 & 4.6 \\
\hline & Both at courthouse & 3 & 3.4 \\
\hline & Total & 87 & 100.0 \\
\hline \multirow{4}{*}{ Interview with the father } & Courthouse & 83 & 92.3 \\
\hline & Home & 6 & 6.6 \\
\hline & Both at courthouse & 1 & 1.1 \\
\hline & Total & 90 & 100.0 \\
\hline \multirow{3}{*}{ Interview with close relations } & Yes & 3 & 2.8 \\
\hline & No & 104 & 97.2 \\
\hline & Total & 107 & 100.0 \\
\hline
\end{tabular}




\begin{tabular}{|c|c|c|c|}
\hline \multirow{3}{*}{ Visit to the mother's house } & Yes & 9 & 8.4 \\
\hline & No & 98 & 91.6 \\
\hline & Total & 107 & 100.0 \\
\hline \multirow{3}{*}{$\begin{array}{l}\text { Suitability of the mother's } \\
\text { house for the child }\end{array}$} & Suitable & 8 & 88.9 \\
\hline & Unsuitable & 1 & 11.1 \\
\hline & Total & 9 & 100.0 \\
\hline \multirow{3}{*}{ Visit to the father's house } & Yes & 8 & 7.5 \\
\hline & No & 99 & 92.5 \\
\hline & Total & 107 & 100.0 \\
\hline \multirow{3}{*}{$\begin{array}{l}\text { Suitability of the father's house } \\
\text { for the child }\end{array}$} & Suitable & 7 & 87.5 \\
\hline & Unsuitable & 1 & 12.5 \\
\hline & Total & 8 & 100.0 \\
\hline \multirow{3}{*}{$\begin{array}{l}\text { The mother's statement } \\
\text { regarding her home }\end{array}$} & Yes & 74 & 75.5 \\
\hline & No & 24 & 24.5 \\
\hline & Total & 98 & 100.0 \\
\hline \multirow{3}{*}{$\begin{array}{l}\text { The suitability of the statement } \\
\text { regarding the mother's home }\end{array}$} & Suitable & 72 & 97.3 \\
\hline & Unsuitable & 2 & 2.7 \\
\hline & Total & 74 & 100.0 \\
\hline \multirow{3}{*}{$\begin{array}{l}\text { The father's statement } \\
\text { regarding his home }\end{array}$} & Yes & 75 & 75.75 \\
\hline & No & 24 & 24.25 \\
\hline & Total & 99 & 100.0 \\
\hline \multirow{3}{*}{$\begin{array}{l}\text { The suitability of the statement } \\
\text { regarding the father's home }\end{array}$} & Suitable & 70 & 93.4 \\
\hline & Unsuitable & 5 & 6.6 \\
\hline & Total & 75 & 100.0 \\
\hline
\end{tabular}

In Table 2, the distribution of the information related to the children's development are shown. According to the table, only $20.8 \%$ of the comments are related to the general development of the child. Information regarding the general development level of only 34 of the 164 children who were involved in a custody battle was included in the reports. When the findings related to the children's social-emotional development are examined, findings regarding only $5.5 \%$ of the children's socialemotional development are found in the file contents. Findings related to other developmental areas are too few to be mentioned. When we look at the results of how the development of the children who are custodial subjects are placed in the report, it is seen that the most important areas of custody evaluation are general development and socio-emotional development. From a holistic point of view, it would not be wrong to say that each developmental area is of individual importance in order for the child to be able to integrate into society as a healthy adult. Development is 
multi-dimensional, versatile and contextual (Santrock, 2012). Development areas are a whole and all areas of development affect each other (Gander \& Gardiner 2004).

Information related to each developmental area has the quality to influence the decision regarding the child's best interest. This is because each child is unique, and each report is independent of each other. Hence, each child should be evaluated individually, each factor should be assessed and a conclusion must be reached 'based on the child only'. For example, when evaluating the causes of growth deficiency in two separate children related to motor development, the factors that cause retardation in motor development may not be significant when deciding on custody for one child. However, for the other child, these reasons may be a serious factor affecting the decision-making process. Or, the cognitive development or social-emotional development of the child may seem normal, however, that doesn't mean that the general development of the child is normal. Hence, if some factors that affect the development are not taken into consideration, it may lead us to a negative consequence, far from the best interests of the child. Thus, all dimensions of development are significant when evaluating the custody. In other words, every dimension of the development should be considered as one of the factors that influence the decision for the best interest of the child. However, Otto et al. (2000) argues that specialists need to make evaluations on various behaviors, capacities, and requirements for deciding on the best interests of the children and the ability of their parents to fulfill the best interests of the children, and with the training that the specialists received in child development, parenting skills, family relationships, and psychopathology, specialists should take the responsibility of supporting the parents and children during the judicial process by providing opinions and recommendations. In Ackermen and Ackermen's (1997) study that evaluate the reports prepared regarding custody, it was ascertained that $92 \%$ of participants had tested or applied scale tests on children (4.8 tests per child), $58.2 \%$ of the tests consisted of intelligence tests such as Wechsler Intelligence Scale-3 for Children or developmental tests, custody-specific perception tests, sentence completion tests, personality tests, and family relationship tests. When the same study evaluates the tests applied to the parents, it was observed that $97.4 \%$ of the participants had tested the parents and the average number of tests applied to the parents was 4.5. The most common test applied to the parents was the Minnesota Multiphasic Personality Inventory (91.5\%). However, in a study conducted by Quinell and Bow (2001), it was affirmed that the applied tests were evaluated with a different angle and that parent-child observations are more significant than the psychological tests applied to the parties and that these tests should be used to generate personal hypotheses but they cannot be considered as the only factor in the decision-making process. Although Quinell and Bow (2001) reported that tests that would be applied to both children and parents should not be used alone for evaluation of custody, it would be essential to support the evaluation with standard scales tests or other tests in the decision-making process, both in terms of evaluating the child's development and 
the significance of obtaining data in the decision-making process related to custody, by determining factors such as the parents parental profiles, psychological state etc.

Information related to each developmental area has the ability to influence the decision regarding the best interest of the child. This is because each child is unique and each report is independent of each other. For this reason, each child should be assessed individually, each factor should be evaluated and a conclusion must be reached 'according to the child'. The same developmental delay has a different causality for each child. Also, the fact that a child is developing normally in one area does not mean that the child's general development is normal. When children are assessed, it is necessary to evaluate all development areas together in coordination. All dimensions of development are important in the evaluation related to custody. For this reason, it is necessary that each developmental area of the child is an influencing factor when making a decision based on his / her best interest.

Table 3

Distributions related to interviews with children

\begin{tabular}{|l|l|r|r|}
\hline & & $\mathrm{N}$ & $\%$ \\
\hline \multirow{4}{*}{ Interviews with children } & Yes & 115 & 70.0 \\
\cline { 2 - 4 } & No & 39 & 30.0 \\
\cline { 2 - 4 } & Total & 164 & 100.0 \\
\hline \multirow{3}{*}{$\begin{array}{l}\text { Where the interview was } \\
\text { conducted }\end{array}$} & Courthouse & 102 & 88.7 \\
\cline { 2 - 4 } & Home & 13 & 11.3 \\
\cline { 2 - 4 } & Total & 115 & 100.0 \\
\hline
\end{tabular}

Table 3 contains information related to interviews with children who were the custodial subject during the custodial decision-making process. Based on these facts, it is seen that $70 \%$ of the children were interviewed and 30\% were not interviewed. In the interviews conducted during the preparation of the reports, $88.7 \%$ were interviewed in a court environment and only $11.3 \%$ of the children were interviewed in a home environment.

It was stated in the report content that the reason 30\% were not interviewed, was due to the age of the children being generally young and the interviewing environment (court) not being appropriate for the child. For non-interviewed children, it was also observed that a decision was reported in relation to custody in the evaluated reports. $88.7 \%$ of the interviews with children were conducted in a court environment. It is believed that unhealthy interviews conducted outside the structured environment of the child's age and development, carried out in the courts with the children and in general with one of the parents present, can affect the process related to custody differently and could make it difficult for the child's best interests to be revealed. Altındağ and Sağlam (2012) stated that in an evaluation related to custody, with a child orientated perspective the specialist should listen to the child 
in the place where he/she feels most comfortable, which is considered as the home environment. Ackerman and Ackerman (1997) found that $90.8 \%$ of participants were interviewed separately with children and parents, and each child was interviewed with their parents. Luftman et al. (2005) addressed the need for single and multiple interviews with children in the assessment process for custody. In the findings of Uner Altuntaş's (2010) study, it was found that in evaluations regarding custody the interviews with children were far from the standards mentioned in the literature. Individual interviews with the child in the home environment and in the form of separate child and parent interviews are important in terms of being able to gather data that has a better chance of being supported by observations.

In a study conducted by Bow and Quinell (2004), as the interviews were conducted with both of the parents and almost all of the children, they emphasized the importance of parent-child observations, psychologists' observation methods differing, that some of them observed during home visits, that some of them prepared a structured environment for observation, and that some made spontaneous observations without preparing a structured environment. They also stated that it would be useful to determine the level of development separately from the children's parents, using various techniques and games. Researchers have mentioned the value and necessity of having this information included in the report so that the developmental needs of the child can be demonstrated and the development can be properly supported. UNICEF (2013) stated that the child's developmental stage should be well-known and the interview technique should be organised accordingly so that the interviews with the children can be successful and the necessary information can be obtained while the report regarding custody is being prepared. It has been argued that a holistic interview should be child-focused at every stage, should take into account the development of the child and that an ecological approach should be adopted. It has been mentioned that in the custodial decision-making process, interviews with children have some projective methods that can be used in the name of getting to know the child and that the use of them can give the expert an idea in the right direction in order to be in the best interest of the child. According to Akyüz (2015), it is necessary to get the opinion and desires about the child's life as the child that demonstrates normal development grows up. For this reason, asking the child's opinion in the process of deciding about custody should become more significant as the age progresses. In a guide prepared for social workers by Lufhtman et al. (2005), it is emphasized that the courts have traditionally been in favor of choices that the older children make. In addition, although the child is small, it is possible to get the opinion of the child by asking questions such as 'Who would comfort you if you had a nightmare?'. Or following questions may be asked to the child: 'With whom would you like to go to school in the morning?' With whom you are happier when someone assists you with the homework? With whom do you like eating? Who would read to you while you go to sleep?'. Unfortunately, if an observation is to be made in the context of the assessed reports regarding these 
interviews, it can be said that it is far from the standards mentioned in the literature for ideal child interviews; such as the environment in which it is conducted, the number of interviews and the frequency, structuring them together with others, structuring them according to the development of the child and using projective methods. However, the interviews with the children constitute the basis regarding custody of the child regardless of the age of the child. When these interviews are properly structured, they provide important clues about the child's wishes and their best interests. For this reason, interviews with the children constitute the basis of evaluations of custody.

Table 4

Process / Distributions related to variables that may affect the custodial decision making process

\begin{tabular}{|c|c|c|c|}
\hline & & $\mathrm{N}$ & $\%$ \\
\hline \multirow{3}{*}{ Test applied to the child } & Yes & 2 & 1.2 \\
\hline & No & 162 & 98.8 \\
\hline & Total & 164 & 100.0 \\
\hline \multirow{3}{*}{ Test applied to the parents } & Yes & 0 & 0 \\
\hline & No & 107 & 100.0 \\
\hline & Total & 107 & 100.0 \\
\hline \multirow{3}{*}{ The child's point of view } & Yes & 83 & 50.6 \\
\hline & No & 81 & 49.4 \\
\hline & Total & 164 & 100.0 \\
\hline \multirow{4}{*}{ The child's wishes } & Mother & 54 & 65.0 \\
\hline & Father & 28 & 33.7 \\
\hline & Both of them & 1 & 1.3 \\
\hline & Total & 83 & 100.0 \\
\hline \multirow{3}{*}{ School visit } & Yes & 4 & 2.4 \\
\hline & No & 160 & 97.6 \\
\hline & Total & 164 & 100.0 \\
\hline \multirow{3}{*}{ Interviewing parents } & Yes & 4 & 3.4 \\
\hline & No & 103 & 96.6 \\
\hline & Total & 107 & 100.0 \\
\hline
\end{tabular}




\begin{tabular}{|l|l|r|r|}
\hline \multirow{4}{*}{$\begin{array}{l}\text { Who the child is staying within } \\
\text { the divorce process }\end{array}$} & Mother & 65 & 60.6 \\
\cline { 2 - 4 } & Father & 23 & 21.5 \\
\cline { 2 - 4 } & Both of them & 14 & 13.0 \\
\cline { 2 - 4 } & Unspecified & 5 & 4.9 \\
\cline { 2 - 4 } & Total & 107 & 100.0 \\
\hline \multirow{4}{*}{ Who provided care since birth } & Mother & 81 & 75.7 \\
\cline { 2 - 4 } & Father & 4 & 5.6 \\
\cline { 2 - 4 } & Both of them & 6 & 3.7 \\
\cline { 2 - 4 } & Unspecified & 16 & 14.9 \\
\cline { 2 - 4 } & Total & 107 & 100.0 \\
\hline
\end{tabular}

Table 4 contains report information that is thought to be influential in the process of custodial decision making. In the Table, it is seen that only $1.2 \%$ of the children are tested in total. The contents of these tests constitute sentence completion tests administered to the child. Parents were not subjected to any tests or inventories. Almost half of the children's opinions were not included. While 65\% of the interviewed children wanted to stay with their mother, $33.7 \%$ said that they wanted to stay with their father. It was decided with only eight of the children who were interviewed that custody would be given to a different parent than whom they wished. In the assessment regarding school visits, it was stated in the reports that only $2.4 \%$ of children had a school visit. It is seen that $4.4 \%$ of the reports included interviews with the main parents. The information in the report regarding which parent provided care for their children since birth suggests that $75.7 \%$ was the mother and 5.6\% was the father.

As stated in the Law on the Establishment, Duties and Trial Procedures of Family Courts, the experts appointed in these courts were pedagogues, social workers, and psychologists (K.n.: 4787). It is thought that applications such as tests or inventories are not done for various reasons including; the majority of the experts who prepare the reports being part of the pedagogical staff; their graduation fields not being suitable for carrying out any tests on children; and the absence of mandatory training for tests and inventories required or provided by the ministry. However, Otto et al. (2000) argues that experts need to make assessments on various behaviors, capacities, and needs in order to take into account the best interests of the children and the ability of their parents to meet their best interests, and with the training that they received in child development, parenting skills, family relationships, and psychopathology, experts should take the responsibility of assisting the parents and children during the judicial process with their interpretations and opinions. In the study conducted by Bow and Quinell (2004), it was mentioned that tests were conducted on most parents, many documents were examined and interviews were conducted with acquaintances and relatives who witnessed the relationship of the 
parents such as carers, family physicians, and therapists. In Ackermen and Ackermen (1997) 's study where reports prepared regarding custody were evaluated, it was found that $92 \%$ of participants had tested or applied scale tests on children (4.8 tests per child), 58.2\% of them were intelligence tests or developmental tests, apart from these custody-specific perception tests, sentence completion tests, personality tests, and family relationship tests. When the tests applied to parents in the same study were evaluated, it was seen that $97.4 \%$ of the participants were testing the parents and the average number of the tests applied to the parents was 4.5. However, in a study conducted by Quinell and Bow (2001), it was stated that the applied tests were approached on a different angle and that parent-child observations are more important than the psychological tests applied to the parties and that these tests should be used to generate personal hypotheses but they cannot be considered as the only factor in the decision-making process. Although Quinell and Bow (2001) reported that tests being applied to both children and parents would not be used solely for assessment of custody, it would be necessary to support the evaluation with standard scales tests or tests in the decision-making process, both in terms of evaluating the child's development and the importance of obtaining data in the decision-making process related to custody, by determining factors such as the parents parental profiles, psychological state etc.

It was seen that half of the children who were interviewed gave their view related to custody. According to Akyüz (2015), a child that displays normal development should value their views and desires greatly regarding the decisions to be made about their life as they grow up. For this reason, asking the child's opinion in the process of deciding about custody should become more important as the age progresses. In a guide prepared for social workers by Lufhtman et al. (2005), it is emphasized that the courts have traditionally been in favour of older children's choices. Even if the child is young, questions such as 'who would comfort you if you had a nightmare?' would still be asked in order to get information regarding the child's perspective. For this reason, it is thought that the number of children referred to in this study is not sufficient and even if the child's age is young, the thoughts and opinions of the child can be collected using various techniques.

Within the scope of the study, the rate of benefiting from auxiliary resources such as the child's school and meetings with close relations and close family is extremely small. In a study conducted by Uner Altuntaş (2010), it was emphasized that in our country school visits are not considered important enough, in assessments related to custody. Otto et al. (2000) stated that experts in assessing custody must include many people in the assessment, including the mother, father, close relations and particularly the children who are the subject of custody. According to Austin (2002), teachers and school staff (principals, guidance counselors, special education teachers) are in a unique position to offer a multidimensional perspective on the child and family participation in the child's academic life. Austin (2002) noted that teacher interviews are important in the custodial decision-making process because 
teachers have more knowledge about important variables and witness critical behaviors related to the child and emphasized that the teacher spent a longer period of time with the child than with the parents. They added that in some cases they can provide useful information because they are good observers and evaluators of both parents and children. It is thought by Austin (2002) that the arguments can be evaluated more healthily by supporting the controversial issues between the parties and the declarations of the children with auxiliary resources. When we look at what these resources may be, they include information such as school notes, developmental, psychological or educational tests, family medical records for parents and children, parental interviews, close relation interviews (relatives, schools, service driver and neighbours), criminal records, pharmacy records, social services records, employment documents, and court information, obtained as a result of the literature search. In the study of Bow and Quinell (2004) the data that formed the basis of the custodial decision-making process was, parental interviews, interviews with children who are the custody subjects (excluding children under the age of five), parental psychological tests, developmental tests for children, home visits, parent-child observations, interviews with close relations and interviews with school personnel. When the findings in the literature and the findings of the study are compared, it is seen that there is little evidence of the use of auxiliary resource data in the assessed reports.

In the process of decision making related to custody, it is seen that the other point which is emphasized by the experts is the attached parent. When the findings obtained at the end of the study are examined, it is generally concluded that the attached parent is usually the mother. According to Bowlby, attachment is vitally important for children. There are three important functions of attachment in human life. The first is having a safe haven to return to while discovering the world, the second is the provision of physical necessities, and the third is the chance to develop a sense of security about life (Tüzün \& Sayar, 2006). The attached parent is critically important for the child's healthy development and social acceptance. For this reason, it is considered that the evaluation of attached parents is necessary for the evaluation process of custody. When we look at the source of the long-term effects of divorce, it is known that it could lead to the insecure attachment to either the primary or secondary bonding figure or both. The inability to achieve secure attachment is associated with a range of emotional problems ranging from childhood to adulthood (Emery, 2012). According to Kelly and Lamb (2000), the investigation of the child's attachment processes is one of the developmental indicators of the child that needs to be assessed in the custody decision-making process. Stahl (2012) noted that experts assessing children should pay adequate attention to the quality of the attachment in their relationship with the parents. 
Table 5

Distributions related to the occupation of the experts and the opinion resulting from the investigation

\begin{tabular}{|c|c|c|c|}
\hline & & $\mathrm{N}$ & $\%$ \\
\hline \multirow{7}{*}{ Expert / expert opinion } & Mother & 72 & 67.3 \\
\hline & Father & 20 & 18.7 \\
\hline & Mother/father & 2 & 1.9 \\
\hline & Joint custody & 0 & 0 \\
\hline & Abolition of custodyi & 1 & 0.9 \\
\hline & Opinion not reported & 12 & 11.2 \\
\hline & Total & 107 & 100.0 \\
\hline \multirow{10}{*}{ Reason for decision } & Child's developmental needs & 41 & 36.0 \\
\hline & Child's participation right & 42 & 36.8 \\
\hline & Parents' common decision & 7 & 6.1 \\
\hline & Possibility of child neglect & 2 & 1.7 \\
\hline & $\begin{array}{l}\text { Fulfilling parental } \\
\text { responsibilities }\end{array}$ & 1 & 0.9 \\
\hline & Connecting parents & 6 & 5.3 \\
\hline & Child's life order & 7 & 6.1 \\
\hline & Unsuitable mother & 2 & 1.8 \\
\hline & Unspecified & 6 & 5.3 \\
\hline & Total & 114 & 100.0 \\
\hline \multirow{3}{*}{$\begin{array}{l}\text { Opinion regarding the } \\
\text { establishment of a personal } \\
\text { relationship between non- } \\
\text { custodial parents and children }\end{array}$} & Opinion specified & 9 & 8.4 \\
\hline & Opinion not specified & 98 & 91.6 \\
\hline & Total & 107 & 100.0 \\
\hline \multirow{3}{*}{$\begin{array}{l}\text { Status of the personal } \\
\text { relationship between non- } \\
\text { custodial parents and children }\end{array}$} & Boarding & 7 & 77.8 \\
\hline & Non-boarding & 2 & 32.2 \\
\hline & Total & 9 & 100.0 \\
\hline
\end{tabular}

As seen in Table 5, in $67.3 \%$ of the assessed reports it was determined that custody of the children was given to the mother and in $18.7 \%$ it was reported that custody of the children was given to the father. In $11.2 \%$ of the reports, no decision regarding who it would be appropriate to grant custody to was reported. While in $0.9 \%$ of the reports it was decided that the custody should be abolished, there were 
no decisions related to joint custody reported. When the experts' reasons for their opinion were evaluated (the opinion in each report is based on at least one or more than one reason), they stated that their opinions were based on 36.8\% of the child's developmental needs, $36.8 \%$ the consideration of the child's right to participate, $6 \%$ reported their opinion on the basis of a joint decision by the parents and again $6.1 \%$ with the emphasis on the attached parent. The reason for the abolishment of custody is due to the parents not fulfilling their responsibilities. In only $8.4 \%$ of the reports examined, an opinion was expressed regarding the establishment of a personal relationship with the non-custodial parent.

From a historical point of view, children used to be considered to be the property of the father, but after the Second World War things took a different form with the contributions of several researchers including child development researchers Mary Ainsworth, James Robertson and John Bowlby, raising the debate over the need to prefer the mother in custodial decision making. In 1951, in a post published by the World Health Organization (WHO) on post-war children in Europe, John Bowlby stated: 'a warm, sincere and lasting relationship between a mother and baby and or small child should be maintained.' This is due to the psychoanalytical hypothesis that fathers are generally less likely to contribute to the development of their children at an early age. From this hypothesis regarding the mother-child relationship, as the preferred custodial parent, priority is given to mothers unless they are deemed to be 'unfit'. However, this situation has changed with the progress of studies directed towards the father and child. After the emergence of the concept of the child's best interest, the parents have equal priority to receive the child's custody (Lufhtman et al., 2005). The majority of the reported opinions about custody in the data obtained as a result of our research are directed at the mother. Within the evaluated reports there are similar decisions in post-World War 2 viewpoints; if both parents were deemed eligible for custody, the mother was preferred and there would be no reason to justify why the child should not be given to the mother. When compared with the cases of custody abroad, it is seen that joint custody has not yet become legal in our country. In some countries, single-parent custody is exceptional, whereas in some countries single-parent custody and joint custody options have equal conditions (Kiremitci, 2012). In a study, Ackermen and Ackermen (1997) found that there were many reasons that affected the decision for joint custody, especially the relationship between the parents; $82.1 \%$ of the parents not clashing and cooperating with each other, $56.6 \%$ the child being attached to both parents, $28.3 \%$ both parents being psychologically healthy, and 16\% it being the parents' wish. However, unfortunately, our country does not yet have a legal subdivision of the concept of joint custody, so experts make their decision based on a single parent. If a statement is to be made in support of the healthy development of the child in the context of the child's best interest, it should be considered that both parents may be eligible to receive custody of the child and that when the parents have a positive attitude towards it, joint custody should be taken into account in the Turkish Civil Code as an alternative option. 
There are many reasons that influence the opinion of experts. Several reasons are mentioned in each report. The highest percentage of these belongs to the right to participate and developmental needs of the child. When we review the parameters that affect the opinions of the experts in the literature, it was observed that there are inferences about which parameters should be effective in the decision-making process for the custody. If we briefly summarize the studies, the development of the child is generally directly or indirectly taken into consideration for the evaluation in many studies that emphasize the necessity. In addition, the studies attach a particular importance to the child's right to participate (Altındağ and Sağlam 2012; Lufhtman et al. 2005; Bow and Quinell, 2004; APA, 1994). Moreover, the child's regular order is one of the variables that guide the opinions of the experts as well. Alexander (1977) emphasized that a child, who has the ability to express himself/herself at any age has the right to express his/her opinion about the custody. According to Article 12 of the United Nations Convention on the Rights of the Child, the child who is capable of forming his or her own views the right to express those views freely in all matters affecting the child, as the child is an active subject of his/her right (BM, 1995). However, the opinions of the children about the custody should be evaluated in parallel with the age, development, and maturity of the child (Polat \& Güldoğan, 2015). It has been also ascertained out that the concept of the 'best interest of the child' constitutes the main concept that influences the opinion of the experts, according to the interviews conducted with the experts. When we examine how the best interests of the child are discussed in the literature, it is comprehended that providing the best interests of the child in the literature is strictly related to the development of the child (Akyüz, 2015; İHOP, 2012; Serdar, 2008). Therefore, the following parameters shall be influential when deciding on the custody for the best interest of the child; the development period of the child, the existence of a retardation in the development of the child, the presence of other factors affecting the development of the child, the existence of challenges specific to the child, the existence of social and environmental conditions that negatively affect the development of the child, which parent would support the child's development in a healthier way (UNICEF, 2013). It should not be ignored that the main tasks of the experts when evaluating the parent are related to the child. While issues such as parental alienation, domestic violence, and conflicts between parents exist, custody evaluations should focus on the needs of children. Experts should collect a variety of data to be able to provide recommendations on the needs of children for the parent, who can best meet these needs (Stahl, 2012). In general, relationships with parents play a very prominent role in the social, emotional, personal and cognitive development of children and there is a significant literature documenting the negative effects of impaired parent-child relationships on children's development and self-regulation (Kelly and Lamb, 2000). Parents should also consider that they need to fulfill various responsibilities so that the child can reach a certain level of development (Lufhtman et al., 2005). Based on these views in the literature; even though the experts emphasize the importance of 
the child development in the reports evaluated during the decision-making process related to the custody, no findings were found regarding the evaluation of the child's development in the content of these reports. Due to the fact that the information about the development of the children is very limited in the content of the reports, it is considered essential to making the necessary arrangements in the content of the custody reports in order to support the development of the child, who is the subject to the custody. In addition, it is necessary for being able to evaluate correctly the parents that would provide the development to the child. Thus, the experts may better support the parameters they advocate. Only a small number of the evaluated reports gave information about the personal relationship that needs to be established with the parent, who did not have the custody. In the event that an opinion is not communicated after the declaration of custody regarding the personal relationship, it would be necessary to open a new case, follow the same legal processing and reevaluate the case. This is considered to increase the burden of the justice system from the expert to the judges, and at the same time, this endangers the child's relationship with the parent, who does not have the custody, and also it causes many unnecessary financial and time-consuming losses for everyone involved in the system. Hence, when the findings of the decisions related to the establishment of a personal relationship with the parent, who doesn't have the custody, have been evaluated from the custody reports, it is considered that the decisions regarding the establishment of personal relationship are not sufficiently included in the reports. The majority of the reports, which mention the necessity to establish a personal relationship, suggests that the child stays overnight. All children who are subject to this decision are going to school or they are older. Kelly and Lamb (2000) approached from a different perspective to establish a personal relationship. In establishing a personal relationship, the general context is that the personal relationship should be established in a way that the child doesn't stay overnight. That means that the stability of the child's life is crucial and that babies should not stay in their father's house to prevent their habits such as sleeping and eating get affected after divorce. However, the researchers commented that these unnecessary restrictions and limiting guidelines were suggested independently from the studies conducted on the child development. Emphasizing that this understanding is outmoded, it needs to be stated that these kinds of suggestions are made without taking into consideration the quality of parent-child relationships, the quality of parental participation, the necessity of establishing a healthy and strong relationship with both parents. Although Stahl (2012) argues that if children stay regularly at the mother's or father's house after the divorce would be beneficial for the children, it is necessary to take into consideration the fundamental requirements suitable for the age of the child. In addition, it is essential that divorced parents communicate about the children and the requirements of them. Considering Kelly and Lamb (2000) 's study, it was concluded that in order to establish a healthy parent-child relationship, including infancy, and to support the development of the child in this direction accurately, 
it is essential to inform the parents about the nature of personal relationship with the parent, who does not have the custody. It is also considered that it is significant to give a decision on how to establish a personal relationship when deciding on the custody in court. In addition, the developmental needs of the child are more important even if the parents have the right to see the child. Focusing on the best interest of the child, the needs of the child should be explained correctly and the decision to establish a personal relationship should be taken in this context (Stahl, 2012; Akyüz, 2015).

\section{Conclusion}

When the information obtained as a result of this research aimed at evaluating the custodial decision process in the context of the development of the child in families separated by divorce in Turkey is put forward, it is concluded that interviews with the parents of the custodial subject are insufficient and that the interviews are carried out in an inappropriate environment, visits to the parents homes were too few to mention and evaluations related to home life were meager. In addition, none of the parents were subjected to any standard tests. Findings related to the development of the custodial subject were not adequate enough to comment. This is supported by the fact that none of the children were evaluated using developmental or psychological tools.

Although most of the interviews were conducted with the children, it is seen that most of these interviews were conducted in inappropriate settings using inappropriate methods and techniques and were far from the appropriate interview method mentioned in the literature, and that it is not possible to observe the child in a healthy manner with these interviews.

In addition to this, factors such as there being little room for auxiliary resources during the evaluation, the contents of the parameters taken into consideration in the decision making process related to the custody, the lack of opinions regarding joint custody, the few opinions about harmony in personal relationships, along with other data proves that this assessment of custody is far from a 'developmental' assessment.

The results from these findings show that while evaluations regarding custody in Turkey are expressed in many places with the emphasis on the development of the children, the reports contain little information about the development of the child. When the child's best interest is considered to be the most important component of child development, it is seen that as a result of these depictions, developing a new system in order to protect the best interest of the child, which is one of the top principles of the law related to custody, and carrying out an evaluation that focuses on child development is necessary. For this reason, with a transdisciplinary approach towards the evaluation of the child's development, it may be advisable to establish 
a higher quality custody evaluation process by preparing a report within the scope of the study done with the relevant field experts. The developmental evaluation should be done in the right way, considering how important the development of children is in their point of view and reports of care. Child development officers must also be involved in the system so that the needs of children can be better assessed individually and joint decisions should be made with transdisciplinary studies. In addition to this general necessity, the addition of various laws and regulations regarding the concept of joint custody, which is not fully included in Turkish legal system, in order to protect the best interests of the child will increase the right decisions being made regarding the development of the child.

Another suggestion that could be made, considering the findings of the interviews conducted with children, is to make arrangements for the preparation of an appropriate observation and interview room equipped with the appropriate materials and prepared in accordance with the child so that interviews with children can be carried out within the courthouse in Turkey.

\section{References}

Ackerman, M.J., Ackerman, MC, (1997). Child custody evaluation practices: A 1996 survey of psychologists. Heinonline, Citation: 30, Fam. L.Q. 565

Akyüz, E. (2015). Child Law ‘Rights and Protection of Children', Pegem Akademi, 4. Edition, Alexander, S.J. (1977). Protecting the child's rights in custody cases. The Family Coordinator, The Family and the Law 26, 4, 377-382

Altında $\breve{g}$, Ö, Sağlam, M. (2012). Roles and functions of family court experts in determining and protecting children's rights during the divorce process, International Participation Child Needs Symposium Proceedings Book

APA, (1994). Guidelines for child custody evaluations in divorce proceedings, Family Law Quarterly, 29, 1, 51-62 [Special Symposium on Working with Mental Health Professionals] Austin, W.G. (2002). Guidelines for utilizing collateral sources of information in child custody evaluations, Family Court Review, 40, 2, , 177-184

Bilici, A.B. (2014). Psycho-social effects of the divorce process on children Cumhuriyet University Faculty of Theology, 18, 2, 79-110

UN, United Nations Convention on the Rights of the Child, (1995). T. C. Official Gazette, 22184, 27. 01.1995 Number of Decisions: 94/6423

Bow, J.N., Quinnell, F.A. (2004). Critique of child custody evaluations by the legal profession. Family Court Review, 42, 1, 15- i27

Bow, J.N., Quinell, F.A. (2002). A Critical review of child custody evaluation reports, Family Court Review, 40, 2, 164-176

Bozkurt, İ. (2010). Rights duties and powers arising from custody of the parent, Master Thesis Buz, S., Düzyurt, K., Sağlam, M. (2015). The evaluations of the social workers working in 
the family court on the social examination reports: Ankara Courthouse Case, Community and Social Work, 26, 2,

Cüceloğlu, D. (2015). Human and Behavior. Remzi Bookstore, 7th Edition p.511 Istanbul

Çetiner, S. (2017). The Institution of Custody: The Historical Development and the Legal Character. Dokuz Eylul University Faculty of Law Journal, 19, 25,

Çınar, E.H. (2015). Determining the relationship between the levels of perception of parents' marital conflicts and their anxiety levels of 9-12 years old children whose parents are in the process of divorce: Case of Izmir Province. Master Thesis

Emery R.E. (2012). Marriage, Divorce and Children's Adjustment, Çeviri: Gezmiş E. O. Türkiye İş Bankası Kültür Yayınları, ISBN 978-605-360-999-5

Fiyakalı, N.C. (2008). Comparison of constant anger levels and anger expression styles of parents with divorced and non-divorced high school students in terms of some variables. Pamukkale University Institute of Social Sciences Master Thesis

Gander, M.J., Gardiner, H.W. (2004). Child and adolescent development. Edit: Prof. Dr. Bekir Onur, Imge Bookstore, 8th Edition

Kelly J.B., Lamb, M.E. (2000). Using child development research to make appropriate custody and access decisions for young children, Family And Conciliation Courts Review, 38, 3,297-231

Kiremitçi, M. (2015). Joint (Common) Custody And Social Perspective In The Process Of Divorce. Istanbul : Legal Publishing

Luftman, V.H., Veltkamp, L.J., Clark, J.J., Lannacone, S., Snooks, H.,(2005), Practice guidelines in child custody evaluations for licensed, Clinical Social Work Journal, 33, 3. DOI: 10.1007/s10615-005-4947-4

Martindale, D.A. (2007), Model standards of practice for child custody evaluation, Family Court Review, 45, 1, 70-91

Ministry of National Education (2013). Family Support Education Guide Integrated with Preschool Program

Otto, R.K., Edens, J.F., Barcus, E.H. (2000). The use of psychological testing in child custody evaluations, Family And Conciliation Courts Review, 38, 3, 312-334

Özdal, F., Aral, N. (2006). Investigation of anxiety levels of children who are devoid of father and live with their parents, Gazi University Kurşehir Faculty of Education Journal, $6,2,255-267$

Öztürk, S. (2006). Relationship between self-esteem and anxiety levels of children between the ages of 9-13 and parents of the same age group with divorced parents. Master Thesis

Polat, O., Güldoğan, E. (2015). Expert opinion in the case of divorce, custody of the importance of detecting, Turkey Bar Association Journal, 118

Quiinell, F.A., Bow, J.N. (2001). Psychological tets used in child custody evaluations, Behavioral Sciences And The Law 19, 491-501

Santrock, J.W. (2016). Lifelong Development, Edit: Prof. Dr. Galip Yüksel, Nobel, Translation from the 13 th edition

Stahl, P.M. (2012), Conducting Child Custody Evaluations: From Basic to Complex Issues, Edit: Gülsen Erden, İlkiz Altınoğlu Dikmeer, Çiğdem Kurdiaki, Velayet Değerlendirmeleri: 
Basitten Karmaşılk Konulara, Türk Psikologlar Derneği Yayınları, 2014

Tatlıoglu, K., Demirel, N. (2016) The phenomenon of divorce as a social reality: a social psychological assessment, Journal of Academic Social Research, 4, 22, 59-73

Tüzün, O., Sayar, K. (2006), Attachment theory and psychopathology, Thinking Man, 19, 1, 24-39

UNICEF. (2013). Child Justice System Staff Training Program - Training Book for Social Workers

Usta, S. (2012), Child Rights and Custody. Istanbul : Twelve Plate Publishing, ISBN: 978-6055373-76-4

Uzun, C.. (2013), Evaluation of depression and social skills in parents with divorced and non-divorced children. Istanbul Arel University Institute of Social Sciences, Department of Psychology Master's Thesis

Üner Altuntaş, G.E. (2010). Evaluation of expert reports in custody decisions made between 2005 and 2007 in Istanbul 1st courthouse of Fatih courthouse, Master Thesis. 